\title{
Ceza Yargılamasında Bilirkişilik ve Uygulama Sorunları*
}

\author{
M. Onursal CíN \\ Dr. Öğr. Üyesi, Necmettin Erbakan Üniversitesi Hukuk Fakültesi, Ceza ve Ceza Muhakemesi Hukuku Anabilim Dalı, \\ onursalcin1@gmail.com (Yazar / Corresponding Author)
}

\begin{tabular}{|c|c|}
\hline Makale Bilgileri & ÖZ \\
\hline $\begin{array}{l}\text { Makale Geçmişi } \\
\text { Geliş: 15.05.2021 } \\
\text { Kabul: 12.06.2021 } \\
\text { Yayın: 12.06.2021 } \\
\text { Anahtar Kelimeler: } \\
\text { Bilirkişilik, Uygulama } \\
\text { Sorunları,Ceza } \\
\text { Yargılaması, Bilirkişi } \\
\text { Raporu, Bilirkişilik } \\
\text { Kanunu. }\end{array}$ & $\begin{array}{l}\text { Bilirkişilik, deliller üst başlığı altında incelenen önemli bir delil elde etme ve değerlendirme aracıdır. } \\
\text { Bilirkşi, sahip olduğu teknik bilgi çerçevesinde hâkime yardımcı olan kişi veya kurumdur. Bilirkişi } \\
\text { olabilmenin en önde gelen şartı, özel bilgi sahibi olmaktır. Zira hâkim, kendi mesleki ve teknik } \\
\text { bilgisiyle çözemediği konuları bilirkişiye danışır. Bilirkişi, hâkimin yardımcısıdır, ama asla hâkimin } \\
\text { yerine geçemez, hâkimlik fonksiyonu ifa edemez. Sadece kendisine sorulan sorulara cevap vermekle } \\
\text { mükelleftir. Bundan fazlası, bilirkişilik görevinin sınırını aşar. Özetle Çözümü uzmanlığı, özel veya } \\
\text { teknik bilgiyi gerektiren hâllerde bilirkişinin oy ve görüşünün alınmasına re'sen, Cumhuriyet } \\
\text { savcısının, katılanın, vekilinin, şüphelinin veya sanığın, müdafinin veya kanunî temsilcinin istemi } \\
\text { üzerine karar verilebilir. } \\
\text { Bu çerçevede ortaya konacak ilk kural, bilirkişiliğin ihtiyari bir mesele oluşudur. Madde metninde de } \\
\text { belirtildiği gibi hâkim bilirkişiye “... başurabilir”. Bilirkişiye başvuru, kural olarak zorunlu değildir. } \\
\text { Hâkim, günlük bilgisiyle ya da mesleki bilgi ve tecrübesiyle çözebileceği hususlarda bilirkişiye } \\
\text { başvuramaz. Bizim sistemimizde hep eleştirdiğimiz, hâkimlerin bir alanda ihtisaslaşamayarak değişik } \\
\text { mahkemelerde görev yapmaları aslında bu yönden bir avantajdır. Bir ceza hâkimi, daha önce farklı } \\
\text { mahkemelerde görev yapmış olduğundan, hukuki konularda da bilgi sahibi olabilir. Ancak hâkimin } \\
\text { zaten hukuka dair her konuda uzman olduğu kabul edilir. Bu çerçevede hâkimin, bir başka hukukçu } \\
\text { olarak bilirkişiye başvurması hukuka aykırıdır. }\end{array}$ \\
\hline
\end{tabular}

\section{Expertise and Its Implementation Problems in Criminal Procedure}

\begin{tabular}{ll}
\hline Article Info & ABSTRACT \\
\hline $\begin{array}{l}\text { Article History } \\
\text { Received: 15.05.2021 }\end{array}$ & $\begin{array}{l}\text { Expertise is a tool that obtains and evaluates important evidence examined under the heading of } \\
\text { evidence. Expert is the person who assists the judge within the framework of his technical knowledge } \\
\text { or institution. The most important requirement for being an expert witness is to have special } \\
\text { Published:12.06.2021 } \\
\text { knowledge. It is because the judge consults an expert on issues that he cannot solve with his } \\
\text { professional and technical knowledge. Expert is a vice-assistant of the judge but can never replace a } \\
\text { judge or function as a judge. Expert is just obliged to answer the questions that were asked to him. }\end{array}$ \\
$\begin{array}{l}\text { Keywore intervention than that exceeds the limit of the duty of an expert. To sum up, in the situations } \\
\text { which require expertise, special or technical knowledge; requesting the opinion of the expert could be } \\
\text { Expertise,Implementati } \\
\text { on Problems, Criminal } \\
\text { Procedure, Expert } \\
\text { Report, Expertise Law. }\end{array}$ & $\begin{array}{l}\text { prosecutor, participant, the attorney or the suspect or the accused, attorney or legal representative. The } \\
\text { first rule to be put forward in this context is that expertise is an optional issue. As it is stated in the } \\
\text { article text a judge "... can apply" to the expert. Application to an expert is not compulsory as a rule. } \\
\text { The judge is responsible for issues that he/she can solve with his daily knowledge or professional } \\
\text { knowledge and experience and he is not allowed to apply to an expert. The thing that we always } \\
\text { criticize in our system, the fact that judges cannot specialize in a certain court and serve in different } \\
\text { courts, is actually an advantage in this respect. However, it is accepted that the judge is already an } \\
\text { expert in all legal matters. This is why it is against the law for the judge to apply to an expert as another } \\
\text { lawyer. }\end{array}$
\end{tabular}

Atıf/Citation: Cin, M.O. (2021). Ceza Yargılamasinda Bilirkişilik ve Uygulama Sorunları, Necmettin Erbakan Üniversitesi Hukuk Fakültesi Dergisi, 4(1), s.170-184.

Plagiarism: Bu makale intihal programında taranmış ve en az iki hakem incelemesinden geçmiştir. // This article has been scanned via a plagiarism software and reviewed by at least two referees.

\footnotetext{
* Bu makale, 12.04.2021 tarihinde, Uluslararası Necmettin Erbakan Hukuk Kongresi’nde tebliğ olarak sunulmuştur.
} 


\section{GíRiș}

Gerek Adli gerek İdari Yargıda, isabetli kararlar verebilmek açısından en önemli müesseselerden biri de bilirkişiliktir. Hele ki Ceza Muhakemesinde maddi gerçeğin yani gerçeğin ta kendisinin bulunmaya çalışıldığı ve ayrıca yaptırım olarak hürriyeti bağlayıcı cezalara hükmolunduğu göz önüne alındığında bilirkişilik kurumunun önemi daha da ön sıralarda yer alır. Ülkemizdeki bilirkişilik uygulamalarının son derece çarpık ve özensiz olduğu göz önüne alındığında, maddi gerçeğe ulaşmanın çok da kolay olmadığı üzüntüyle ifade edilmelidir. Özellikle sınırını aşan ifadelerle dolu bilirkişi mütalaalarının kabul görmesi ve kusur oranının hâkime bırakılması gerekirken, bilirkişilerin bazen kasıtlı bazen de bilgisizce sınırlarını aşarak yargilamaya olumsuz bir yön verdikleri görülmektedir. Ülkemizde gerek hâkimlerin iş yoğunluğu gerek Yargıtay'ın bu yöndeki içtihatları çerçevesinde bilirkişilik ihtiyarilikten çıkmış, yargılamanın zorunlu bir aşaması haline gelmiştir. Bu durum uygulamanın "bilirkişi adaleti" çerçevesinde tecelli ettiği yönünde haklı bir eleştiriyi de beraberinde getirmektedir. Öyle ki pek çok davada, aynı yönde iki bilirkişi raporu lehine gelen taraf yargılamada haklı çıkmaktadır. Yıllardır hem kanun koyucunun çabaları hem de doktrin ve uygulamacıların haklı eleştirileri bulunmasına rağmen anılan müessesenin sorunlu işleyişi bir türlü giderilememiştir. Oysa ki konuyla ilgili Ceza Muhakemesi Kanununda son derece ayrıntılı düzenlemeler mevcuttur. Bununla da yetinilmemiş 2016 senesinde 6754 sayılı kanun numarasıyla müstakil bir Bilirkişilik Kanunu ihdas edilmiş ve hemen akabinde konuyla ilgili yönetmelik çıkarılmıştır. Fakat hala sorunlu işleyiş devam etmektedir. Bir hukuk devletinde olmaması gereken şekilde, kanunların uygulaması uygulayanların keyfiyetine birakılır ve kanunu uygulamamanın yaptırımları tatbik edilmezse ne kadar yeni düzenlemeler yapılırsa yapılsın yara kanamaya devam edecektir. Bu çalışmamızda bilirkişilik müessesesi ile ilgili temel düzenlemeler özet olarak verilecek, daha ziyade uygulama sorunları ve çözüm önerileri üzerinde durulacaktır.

\section{I-Genel Olarak Bilirkişilik}

Bir davada gerçeğin ortaya çıkartılması çabası sırasında zaman zaman çözülmesi gereken sorunlarla karşılaşılır ve bunların çözümü özel ve teknik bilgiyi, bilimsel bir çalışmayı gerektirebilir. Uyuşmazlığın sonlandırılması bakımından önemli olan maddi olayın ispatı için bir takım sorunların çözülmesi zorunlu olmaktadır. Ancak bu sorunlar, çözümü için uzmana gitmeyi ondan yardım almayı gerektirir nitelikte olabilmektedir. Böyle bir durumda hâkim, mahkeme, yasanın izin verdiği hallerde Cumhuriyet Savcısı kendilerine yardımcı olması için uzman kişilere başvurmaktadır. Hatta bu başvuru hâkim için bazen bir zorunluluk oluşturmaktadır. Bilirkişi, çözümü uzmanlık, özel veya teknik bilgiyi gerektiren durumlarda oy ve görüşlerini almak üzere kural olarak hâkim veya mahkeme tarafindan atanan, tarafsız kimsedir. ${ }^{1}$ Öte yandan bilirkişi, CMK 63. Maddesi çerçevesinde çözümü uzmanlığı, özel veya teknik bilgiyi gerektiren hallerde oy ve görüşünü sözlü ya da yazılı olarak vermesi için başvurulan gerçek veya tüzel kişiyi ifade eder" biçiminde tanımlanmıştır. Bilirkişiye başvurulduğunda bilirkişi temelde üç hususta hâkime yardımcı olacaktır.1-Genel tecrübe kurallarını bildirerek 2-Özel ve teknik bilgi sahibi olan bir kimsenin gözlemleyip algılayabileceği olguları belirleyerek 3-Özel ve teknik eğitimle

${ }^{1}$ Çakmut Yenerer, Özlem. “Cinsel Taciz Suçu ve Ceza Muhakemesi Kanununa göre Bilirkişilik Kurumu” Ceza Hukuku Dergisi, C.4, S.11, 2009, s.135. 
öğrenilebilecek bilgilere bilimsel kuralları uygulayıp sonuç çıkartarak ${ }^{2}$. Genel bilgilerle çözülmesi gereken hususlar hakkında bilirkişi yardımına müracaat etmek için geçerli bir sebep bulunmamaktadır. Ancak genel bilginin sınırlarının ne olduğunun tespiti önemlidir. Genel bilgi kavramı ile hâkimin genel ve hukuki bilgisinin çerçevesini ve muhatabını gerek hukuk fakültesindeki öğrenimi sırasında, gerekse hâkimlik stajı aşamasında ve gerekse de hizmet içi eğitim faaliyetleri dolayısıyla ve mesleğini icra ederken edindiği mesleki eğitim ve deneyimi belirlemektedir. Belli bir öğrenim görmüş herkesçe bilinebilecek teknik ve bilimsel kurallar ile hâkimin hayat tecrübelerine dayanarak çözüme kavuşturabileceği konular, bilirkişiye gerek olmayan genel bilgi konularıdır. Genel bilgi ne hukukta, ne de başka bir alanda uzman olmayı gerektirmeyen o hususu bilen herkesin elde edebileceği bilgidir.

Bilirkişi incelemesindeki yöntem ve esaslar Bilirkişilerin genel olarak hangi yöntemlerle çalışmalarını sürdürüp rapor vereceklerine dair yöntem ve esasları gösteren bir Yargıtay kararı yok ise de; Amerika Birleşik Devletlerinde federal mahkemeler, Yüksek mahkeme tarafından 1993 yılında belirlenen ve Bilirkişilikte "Daubert Standartları" olarak bilinen kuralları baz almaktadır. "Daubert Standartları"na göre, hakimler bilirkişi sorgulamasının bilimsel geçerliliğinin metodolojik ve mantıksal temelleri bulunup bulunmadığını ve metodolojik temellerin yargılama konusunu oluşturan uyuşmazlığa uygulanmasının mümkün olup olmadığına dair bir ön inceleme yapacaklardır. Bu ön inceleme, bilirkişi görüşlerinin bir teste tabi tutulması anlamına gelmektedir. Buna göre bilirkişi açıklamalarının; I. Sınırları belirlenmiş ve bunun test edilebilir olması gerekir. II. İncelemeye ve değerlendirmeye tabi tutulabilir olması gerekir. III. Alınan bilginin hata oranı, istatistiksel olarak belirlenebilir olmalıdır. IV. İlgili bilim çevresinde kabul görmüş olmalıdır ${ }^{3}$

Bilirkişinin kim olacağı ve sayısının belirlenmesinde hâkim yetkilidir. Bilirkişiler, bölge adliye mahkemelerinin yargı çevreleri esas alınmak suretiyle bilirkişilik bölge kurulu tarafından hazırlanan listede yer alan kişiler arasından seçilir. Ancak, kendi bölge listesinde ilgili uzmanlık alanında bilirkişi olmasına rağmen, diğer bir bölgedeki bilirkişinin, görevlendirme yapılan yere daha yakın bir mesafede bulunması durumunda, bu listeden de görevlendirme yapılabilir. Kanunların belirli konularda görevlendirdiği resmî bilirkişiler öncelikle atanılar. Kanunda bahsedilen listelere, daha önceden, bilirkişilik yapmak üzere başvuran ve uygun görülerek bilirkişilik yapmasına izin verilen kimseler yazılır. Bu kimseler Bilirkişilik Kanununun 10.maddesinde belirtilen hususiyetleri taşımak zorundadırlar. Bilirkişilik müessesesine başvurmak her ne kadar ihtiyari ise de, kanundan kaynaklanan bazı istisnalar da mevcuttur. Bunlara zorunlu bilirkişilik halleri denir. Bu hallerde hâkimin, mutlaka bir uzman yardımından faydalanması gerekir, bu durumda meseleyi kendi başına çözümleyemeyeceği hususunda yasal bir faraziye mevcuttur. Bu gibi durumlarda başta Adalet Bakanlığına bağlı olarak çalışan Adli Tıp Kurumu olmak üzere kanunlarca yetkilendirilmiş bazı tüzel kişiliklerin resmi bilirkişi olarak görev yaptığını söylemeliyiz. Söylenildiği gibi, hakim ya da C.Savcısı özel ve teknik bilgiyi gerektiren konuda kişisel ilgileri nedeniyle bilgi sahibi olsalar da konu hakkında uzmanından görüş almak zorundadırlar. Dolayısıyla kişisel bilgi bilirkişiye başvurma yükümlülüğünü ortadan

\footnotetext{
${ }^{2}$ Yurtcan Erdener. Ceza Yargllaması Hukuku, İstanbul 2005, s.377.

${ }^{3}$ Karaburun, Gökhan. "Karar Örnekleriyle Yargıtay'ın Bilirkişiliğe Bakışı ve Bilirkişiliğin Sorunları”Adli Tıp Bülteni, C.22, S.3, 2017, s.203.
} 
kaldırmamaktadır. ${ }^{4}$ Prensip bu olmakla beraber Yargıtay özellikle tıbbi uygulama hatalarıyla ilgili vermiş olduğu geçmiş kararlarda aynı fikirde olmadığını isabetli olarak vurgulamaktadır. Yargıtay’a göre hekimin mesleki değil meslek dışı dikkati ile bile yapmaması gereken hatalardan kaynaklanan zararlarda konunun bir uzman önünde incelettirilmesine gerek yoktur. ${ }^{5}$

Hâkim, bir kişi veya heyete bilirkişi mütalaası elde etmek amacıyla dosyayı gönderdiğinde gelen raporla kural olarak bağlı değildir. Zira bilirkişi mütalaası bir delil değerlendirme aracıdır ve ceza yargılamasında hâkim, delilleri serbestçe takdir eder. Bununla beraber hâkim, mütalaayı yeterli bulmazsa, mütalaanın genişletilmesi için dosyayı aynı kişiye yollayarak daha ayrıntılı bir rapor isteyebileceği gibi, bir başka kişiye de yollayabilir. Hatta bu iki bilirkişinin raporları birbiriyle çelişmekte ise, hâkim, üçüncü bir kişiyi de bilirkişi olarak tayin edebilir. Ancak bunlar hep zaman kaybıdır. Bu yüzden bilirkişi dikkatle belirlenmelidir. Özellikle tutuklu işlerde raporların gecikmesinden dolayı insanlar çok uzun süreler özgürlüklerinden mahrum kalabilmektedirler.

Bilirkişilerin de tıpkı hâkim gibi reddi, çekinmesi ve yasaklanması mümkündür. Hâkimin reddini gerektiren sebepler, bilirkişilerin reddi için de aynen geçerlidir (m. 69). Hatta bunun usulü de, yine hâkimlerin reddinin usulünde olduğu gibidir. Tanıklıktan çekinme hakkına sahip olan bir kimse, bilirkişilikten de çekinebilir (m. 70). Bilirkişinin yasaklılık haline örnek olarak m. 87/3 verilebilir. Buna göre, ölen kimseyi son hastalığında tedavi eden doktora otopsi yapma görevi verilemez. Öte yandan bilirkişi üstlendiği görevi tarafsız olarak ve dürüstlük ilkesi çerçevesinde ifa etmekle yükümlüdür. Kasten gerçeğe aykırı bilirkişilik yapması durumunda TCK md 276 hükmü uygulanacaktır. Bilirkişi görevini yaptığı sırada gerek TCK md 6 gerek Bilirkişilik yönetmeliği çerçevesinde kamu görevlisi olarak nitelendirilmektedir. $\mathrm{Bu}$ nedenle görevini gerçekleştirdiği esnada göreviyle ilgili suç işlemesi durumunda kamu görevlilerine yönelik düzenlenmiş bazı özgü suçlardan da sorumluluğu cihetine gidilebilecektir. Örneğin rüşvet suçu açısından bilirkişilik TCK 252/2 uyarınca nitelikli hal olarak kabul edilmiştir. ${ }^{6}$

\section{II- Bilirkişinin ve Raporunun Hukuki Statüsü}

Bilirkişilik statüsü, kanunda tanıklık statüsüyle paralel olarak düzenlenmiştir. Kanunun 62. maddesi, bilirkişilikle ilgili olarak, tanıklığa ilişkin hükümlerin bilirkişilik hükümlerine aykırılık teşkil etmeyenlerinin ortak hüküm olduğunu belirterek tanıklık hükümlerine atıf yapmaktadır. $\mathrm{Bu}$ çerçevede, bilirkişinin de tanık gibi üç temel ödevi mevcuttur. İlk ödevi, mahkeme önünde hazır bulunmaktır. Ancak, bilirkişiler çok istisnai durumlarda mahkeme önünde hazır bulunurlar. Uygulamada hâkimler, genellikle bilirkişilerin hazır bulunmalarına gerek görmez. Bunun yerine bilirkişilerin yazılı beyanları söz konusu olur. Bilirkişi, dosyayı almak üzere mahkemeye

\footnotetext{
${ }^{4}$ Yokuş Sevük, Handan. “Ceza Muhakemesi Hukukunda Bilirkişilik”, İHFM, C.64, S.1, 2006, s.53.

${ }^{5}$ Uyuşmazlık karaciğer kistinden rahatsız olan müştekinin devlet hastanesinde davalı doktor tarafindan ameliyat edilirken karnında koher pensinin unutulmasından doğan zarara ilişkindir.Olayın herhangi bir uzman önünde incelettirilmesine gerek yoktur.Çünkü bir operatörün ameliyat sırasında mesleki değil meslek dişı dikkatinin bile böyle bir olaya asla meydan vermemesi gerekir.Buna rağmen Yüksek Sağlık Şürasının olay kendisine gönderilince verdiği 26.11.1973 tarih ve 6669 sayılı raporunda, olayın en normal olan dikkat ve özen zorunluluğunu bir tarafa bırakarak büyük ve karmaşık ameliyatlarda böyle olayların görülebileceğini mütalaa etmesi yersizdir.Y.4.HD 11.12.1976 E.4250 K.1393.Kararı Aktaran Hancı Hamit, Malpraktis, Ankara 2002, s.25-26.

${ }^{6}$ Sevük Yokuş, s.101.
} 
gitmelidir. Bilirkişinin adliyeye giderek dosyayı alması ve çağırdığında hâkimin önünde hazır bulunması, ödevidir.

Bilirkişinin bir diğer ödevi, beyanda bulunmadır. Bilirkişi, beyanlarını sözlü ya da yazılı olarak üç ay içerisinde mahkemeye ulaştırmak zorundadır. Bu süre içinde tamamlayamazsa, kendisini atayan merci, üç ay daha süre verebilir. Üçüncü ve son yükümlülüğü ise yemin etmedir. Bilirkişinin bir başka yükümlülüğü ise, yemin etme ödevidir. Aynı şekilde, bilirkişinin yemin etmeksizin mütalaa sunması, hukuka aykırılık oluşturacaktır. CMUK'a göre bilirkişiler, dosyayı adliyeye giderek alırken yemin etmekteydiler. Yeni sistemde ise, Listelere kaydedilen bilirkişiler, bilirkişilik bölge kurulu veya bulunduğu yer il adlî yargı adalet komisyonu huzurunda "Görevimi adalete bağlı kalarak, bilim ve fenne uygun olarak, tarafsızlıkla yerine getireceğime namusum ve vicdanım üzerine yemin ederim." sözlerini tekrarlayarak yemin ederler.(CMK 64/5) Eğer hâkim, liste dışından bir kimseyi bilirkişi tayin ederse, bu kişinin adliyeye gelerek, eski sistemde olduğu gibi, kendisini atamaya yetkili merci (hâkim) önünde yemin etmesi gerekir. Ancak uygulamada genellikle atamaya yetkili merci önünde değil de, mahkeme kaleminde yazı işleri müdürünün önünde yemin edildiği görülebilmektedir. Hatta yemin etmeyip sadece teslim tutanağına imza atarak dosyaları aldıkları da bilinen bir gerçektir. Unutulmamalıdır ki Bilirkişi, kanunen yemin yükümlülüğü altındadır ve yemin, bilirkişiliğin kurucu unsurudur.

Bilirkişi incelemesinin hukuki niteliği hakkında yasada net düzenleme bulunmamakla birlikte, CMK m. 62'de tanıklara ilişkin hükümlerin bilirkişiler hakkında da uygulanacağı ifade edilmiştir. $\mathrm{Bu}$ nedenle bilirkişi incelemesinin tanık ifadesi gibi bir delil mi, yoksa delillerin değerlendirilmesi vasıtası mı olduğu tartışmalıdır. Öğretide bilirkişi mütalaasının bazı hallerde delil, bazı hallerde delilleri değerlendirme aracı olduğu kabul edilmektedir. ${ }^{7}$ CMK m. 62 gerekçesinde "bilirkişiliğin kendisi bir delil olmamakla birlikte, bilirkişi incelemesi sonucu elde edilen delil, iz, eser ve emare delildir. Başka bir deyişle bilirkişilik, delillere ulaşmak için bir araçtır. ” denilmek suretiyle delil olmadığı görüşü benimsenmiştir.

CMK gerekçesinde her ne kadar bilirkişiliğin delil olmadığı açıklanmış ise de; doktrinde baskın olan bu görüşe göre, bilirkişi raporları veya açıklamaları kendine özgü bir delildir. Çünkü, bilirkişi görüşü neredeyse delil kadar hükme etkili olabilmektedir.

Başka bir görüşe göre bilirkişinin yaptığı iş, yargısal nitelikte bir danışmanlık hizmetidir. ${ }^{8}$ Zira Bilirkişinin yapacağı inceleme sonrasında çeşitli saptamalar yaparak bunu mahkemeye bildirmesi durumunda bilirkişinin delil yaratması söz konusu olmayıp sadece önceden var olan, ancak mahkemenin elde edilmesi için gerekli bilgi ve donanıma sahip olmadığı bir veriyi mahkemeye sunması söz konusudur.

Yargıtay 1. CD.nin 01.03.1991 gün ve 391/559 say1lı kararında bilirkişi görüşünü, delil hakkında yapılmış bir değerlendirme beyanı olarak kabul etmiştir. ${ }^{9}$ Bilirkişi, incelemesini hakimin

\footnotetext{
${ }^{7}$ Dülger, İbrahim. “Ceza Muhakemesi Kanunundaki Bilirkişi İncelemesine İlişkin Düzenlemelerin Değerlendirilmesi”, GÜHFD, C. 11, S.1-2, 2007, (Yrd. Doç. Dr. İbrahim Ongün’e Armağan), s. 672.

${ }^{8}$ Deryal, Yahya. Türk Hukukunda Bilirkişilik, Seçkin Yayıncılık, Ankara 2015, s. 23.

9 Dönmez, Burcu. "Yeni CMK'da Bilirkişi Kavramı" Dokuz Eylül Üniversitesi Hukuk Fakültesi Dergisi, C.9 İzmir 2007, s.1148, dn. 18 .
} 
yerine geçerek yaptığı için sonuçta hakim onunla bağlı değildir. Çünkü bilirkişi hakimin yardımcısı olarak çalışmıştır. Bu nedenle hakim, bilirkişilerin bilirkişisidir (peritus peritorum).

Her ne kadar bilirkişi yaptığı inceleme ile değerlendirme faaliyetinde hakime yardımcı olup ona yol gösterse de yargılama süresince delillerin takdiri daima hakime aittir. Kanaatimce bilirkişi görüşü hem delil elde edilmesi hem de delil değerlendirme aracıdır ancak başlı başına delil değildir. Delil bilirkişi incelemesi sonucunda ortaya çıkan, elde edilen eser, iz ya da emaredir.

Teknik; fizik, kimya matematik gibi bilimlerden elde edilen verileri iş ve yapım alanında uygulamadır.Teknik bilgi ise uygulamaları yapmaya yeterli bilgi olarak ifade edilebilir.Ayrıca kurum kuruluş ve yetkili kişilerce belirlenmiş ve genel nitelik kazanmış teknik standartlar da teknik bilgi kavramı içerisinde değerlendirilmektedir. ${ }^{10}$

\section{III- Bilirkişi Beyanının Sınırlamaları}

Bilirkişi, beyanda bulunurken (raporunu yazarken) belirli sınırlamalara tâbidir. $\mathrm{Bu}$ sınırlamalar şunlardır:

Bilirkişi, hiçbir zaman hâkimin görev alanına giren bir konuda yorum yapamaz. Yani, hukuki konularda değerlendirme yapmamalıdır. Bilirkişi, kendisine hangi soru sorulduysa ancak onu cevaplandırabilir. Mesela, taksirli bir suça ilişkin bilirkişiden mütalaa istendiğinde, bilirkişi, sadece failin bu konuda düzenlenmiş davranış kurallarına riayet edip etmediği, davranışının tedbirsizlik, dikkatsizlik gibi unsurların ürünü olup olmadığı yönünde beyanda bulunabilecektir. Asli kusurlu veya Tali kusurlu gibi belirlemeler hâkime aittir. Hâkimin de hukuki sorunlar için bilirkişiye başvuramayacağı ise unutulmaması gereken bir husustur. Hâkimin hukuki bilgi ile çözümlenmesi mümkün olan konularda, bilirkişi incelemesine başvurulamayacağına dair açık hükmünün, 1985 tarihinden önce Kanun' da bulunmadığı dönemde de, Yargıtay çeşitli kararlarında hâkimin genel ve hukuki bilgi ile çözümü mümkün olan konularda bilirkişi incelemesi yaptıramayacağını belirtmekteydi. Bununla ilgili bir Yargıtay kararında, hâkim ve Cumhuriyet savcısının kendi bilgisi, kültürü ve müktesebatı ile önüne gelen bir konuyu çözümlemek niteliğine sahip bulunduğuna, ihtisasla ilgili bulunmayan hâllerde bilirkişi mütalâasına başvurmaya gerek olmadığına işaret edilmiştir ${ }^{11}$.

Ancak bir görüşe göre Uluslararası ilişkiler nedeniyle karşılaşılabilecek durumlardan olan "yabancı ülkede işlenen bir suçun Türkiyede yargılanması halinde TCK md 19 çerçevesinde yabancı ülke mevzuatı ve uygulaması bakımından hukukçu bilirkişiden yararlanılabilmesine olanak tanınması da gereklilik olarak gözden uzak tutulmamalıdır. ${ }^{12}$ Haklılık payı olsa da kanaatimizce böyle bir sorun, bakanlıkça çözülebilir.D1ş ilişkiler dairesindeki uzmanlarca tercüme edilecek başka ülkelere ait ceza mevzuatları UYAP üzerinden hakimin kullanımına açılabilir. Böylece zaman kaybına da mahal verilmez.

Yeni Bilirkişilik sistemimize göre, kusurun matematiksel oranlarla ifadesi mümkün değildir. Bilirkişiler artık 2/8, 6/8 gibi oranlarla kusur belirtip, bilirkişi raporu düzenleyemezler. Ancak, bununla ilgili olarak kanuni bir düzenleme de mevcut değildir. Bu husus, yalnızca TCK

\footnotetext{
${ }^{10}$ Yenerer Çakmut, s. 137.

${ }^{11}$ Yargitay 8. CD’nin 13.10.1975 tarih ve 1975/6525 E- 1975/5960 K. sayılı karar1.

12 Ünver Yener, “Ceza Muhakemesinde İspat, CMK ve Uygulamamız”Ceza Hukuku Dergisi, C.1, S.2, 2006, s.171.
} 
m. 22'nin gerekçesinde yazmaktadır. Bu tarz bir düzenlemenin geçerli olduğunu savunmak çok da mümkün değildir zira gerekçe madde metnine dâhil değildir. Bu hususta derhal CMK içerisinde veya Bilirkişilik mevzuatı içerisinde bir düzenleme yapılması gerekmektedir. Uygulamada bilirkişiler hala bu şekilde raporlar vermekte, ancak gelen itiraz üzerine hâkim itirazı kabul etmeyerek raporu geçerli saymaktadır. Öte yandan Yaralama suçlarına ilişkin bilirkişi raporlarının Adli Tıp kriterleri(ATK) olarak adlandırılan puanlama çerçevesinde yapıldığı da bilinen bir gerçektir. Fakat bu tamamen teknik bir konu olup, basit tıbbi müdahale ile giderilebilme ve kemik kırığının vücut fonksiyonlarına etkisinin değerlendirilebilmesi için bilinen daha elverişli bir yol bulunmamaktadir.

CMK m. 67/6 ve m. 68/3 hükümlerinde uzman mütalaasından bahsedilmektedir. CMUK döneminde, avukatlar, işin içinden çıkamadıklarında ya da o konuyla ilgili Yargıtay kararı da bulamadıklarında, hâkimi ikna edebilmek amacıyla, uzman görüşü alarak dosyaya koymaktaydılar. $\mathrm{Bu}$ uzmanlar genellikle, Üniversitelerde görev yapan öğretim üyelerinden oluşmaktadır. Bununla beraber hâkimlerin bu uygulamaya pek sıcak bakmadıkları, dosyada olan bu mütalaalara pek de itibar etmedikleri bilinen bir gerçektir. CMK, CMUK'tan ayrılarak bu konuyu bir kanun hükmü olarak düzenlemiştir. Hatta, CMK sistemine göre avukatlar, uzman bilirkişi sıfatıyla kişiyi duruşmaya getirerek dinletebileceklerdir. Bu durum hukuki konulara müteallik olmadığı sürece bir sakınca arz etmez kanaatindeyiz. Bu görüşümüzün temel sebebi gerek Ceza Muhakemesi Kanununun gerek Bilirkişilik Mevzuatının hukuki bilirkişiliğe cevaz vermemesidir.

Adalet Bakanlığı tarafından 2010 yılında hazırlanan "Bilirkişilik" konulu İnceleme Raporunda "Bilirkişilik uygulamalarında temel sorunlardan biri, mevzuatta açıkça yasaklanmış olmasına răgmen, hâkimlik mesleğinin gerektirdiği hukukî bilgi ile çözümlenebilecek konularda hukukçu bilirkişilere müracaat edilmesi" "hâkimlik mesleğinin gerektirdiği hukukî bilgiyle çözümlenmesi mümkün olan konularda bile sıklıkla bilirkişi görevlendirildiği ve bilirkişinin adeta hâkimin yerine geçerek yargı yetkisini kullandığı" hususları eleştirilmiştir. Her ne kadar uzman mütalaası CMK tarafindan 67/6 fikrasında yasal zemine kavuşturulmuşsa da bu uzmanın yargılama konusu olay hakkında hukuki değerlendirmelerde bulunması aynı problemi yaratacaktır. Hukuki konularda bilirkişilik yapabilmek için listeye kaydolmaya kanunen izin verilmediği yerde, taraf bilirkişisi olarak da bu faaliyetin yapılması mazur görülmemelidir. Doktrinde " bilirkişi raporunda hukuki değerlendirmeler bulunması, mevcut uygulamamız bakımından, farkında olmadan (kanaatimce çok gerekli) bir işlev görmektedir. Şöyle ki, ancak böyle bir rapor sayesindedir ki, taraflar, mahkemenin kararının muhtemelen hangi hukuki değerlendirme esas alınarak verileceğine dair, üzerinde tartışabilecekleri, neden yanlış yahut doğru bulduklarını izah edebilecekleri bir zeminden haberdar olabilmektedirler. Öte yandan, Uzman görüşünün hukuki bir değerlendirme ihtiva edebileceği konusunda hiçbir tereddüt yoktur." şeklinde görüşler bulunsa $\mathrm{da}^{13}$ bu yaklaşıma Anayasanın ve Kamu hukukunun temel prensiplerinden biri olan eşitlik ilkesi çerçevesinde sıcak bakmak mümkün değildir. Söz konusu uzman görüşleri hukukçu akademisyenlerden ciddi meblağlar karşılığı alınmaktadır. Bu durum görüş almaya madden imkanı olmayan taraf için bir eşitsizlik yaratmaktadır. Ayrıca yukarıda da

\footnotetext{
${ }^{13}$ Atalı Murat, "6754 sayılı Bilirkişilik Kanunu ve Hukuki konularda Bilirkişilik” Ankara Üniversitesi Hukuk Fakültesi Dergisi, C.65, S.4, s.3277.
} 
değindiğimiz gibi hakimler bu tip raporlara çok sıcak bakmamakta, kendilerine işlerinin öğretildiği duygusuna kapılmaktadırlar. Mademki hukukçu bilirkişi atanması yasada sakıncalı görülmektedir, aynı sakıncanın hukuki konularda görüş bildiren taraf bilirkişileri açısından da kabulü gerekmektedir. Hukuki konuda rapor hazırlayan uzmanın yargılamayı yapan hakim veya hakimlerin geçmişte hocalığını yapmış olma ihtimali ise hakim açısından tamamen tarafsızlı̆̆ tehlikeye düşüren bir durum olarak nitelendirilmelidir. Yargılama bu tip şüpheleri, varsayımları bünyesinde barındırmamalıdır. Bununla beraber CMK nun 67/6. Fıkrasındaki metin içerisinde, hukukçu akademisyenlerin rapor yazmasının sakıncalı olmadığı aksine faydalı olduğu huşular da vardır. Eğer bu tip bir mütalaa doğrudan yargılama konusu olaya ilişkin değil de bilirkişinin raporunun hazırlanmasında değerlendirilmek üzere sunulursa son derece faydalı olabileceği kanaatindeyiz.

\section{IV-Bilirkişi Raporlarındaki Sorunlar}

Bilirkişilik alanındaki sorunları azaltmak ve uygulamaya kurumsallık getirmek maksadı ile kabul edilen 6754 sayılı Bilirkişilik Kanunu çerçevesinde Adalet Bakanlığı uhdesinde bir merkez teşkilatı oluşturulmuştur. ${ }^{14} \mathrm{Bu}$ teşkilat içinde yer alan Bilirkişilik Daire Başkanlığı, "Bilirkişilerin uyacağı rehber ilkeler ve bilirkişi raporunda bulunması gereken standartlar" başlığı altında bilirkişilik yapacaklara yönelik olarak ayrıntılı bir rehber hazırlamıştır. ${ }^{15}$ Otuziki ilkeden oluşan bu rehberde yazılan raporun içeriğine yönelik en önemli gördüklerimiz aşağıda sıralanmıştır.Buna göre;

1-Bilirkişi, görevlendirildikten sonra yapacağı ön inceleme sonucunda konunun kendi uzmanlık alanına girmediğini tespit ettiğinde en geç bir hafta içinde görevlendirmeyi yapan merciye durumu bildirecek ve görevlendirmeyi kabul etmeyecek.

2-Bilirkişi, incelemesini yaparken hak ve adaletin gerçekleşmesinde hakime yardımcı olacağından, bu sorumluluk bilinciyle azami dikkat ve özen göstererek kendisine sorulan tüm sorulara cevap verecek biçimde raporunu hazırlayacak.

3-Bilirkişi, görevlendirme konusu hakkında uzmanlık alanına girmeyen, uyuşmazlığa ve sorunun çözümüne doğrudan etkili olmayan bir durumla karşılaştığında raporunda kesinlikle bu konuda herhangi bir belirleme yapamayacak, görüş açıklayamacak.

\footnotetext{
${ }^{14}$ Eleştiriler için bkz Atalı, s3276-3277 Yazar bu yapılanmayla ilgili “6754 sayılı Kanun’un yeni ve büyük bir buluşmuş gibi gösterip, yaşanan sorunlara çözüm olarak sunduğu husus, özü itibariyle bölge adliye mahkemeleri adalet komisyonları tarafından yerine getirilen idari görevlerin, biraz farklılaştırılarak Adalet Bakanlığı Hukuk İşleri Genel Müdürlüğü bünyesinde oluşturulan bir Bilirkişilik Dairesi (m. 6) ile bölge adliye mahkemesi kurulu bulunan yerde oluşturulan bilirkişilik bölge kurullarına (m. 7, m. 8) verilmesinden ibarettir. Bunun yanında bir de Danışma Kurulu diye adlandırılan, gerek üyelerinin görev konumları ve gerekse 28 kişilik hantal yapısıyla (m. 4) hiçbir fonksiyon yerine getiremeyeceği aşikâr olan bir kurul getirilmiş ve kendisine danışma ve öneri işi (m. 5) verilmiştir. Özellikle Adalet Bakanlığı bünyesinde oluşturulan Dairenin bilirkişilerle ilgili görev ve yetkileri ile bilirkişinin statüsü göz önünde bulundurulduğunda, bunun yargı bağımsızlığı açısından ortaya ciddi endişeler çıkaracağı açıktır. Tamamı bağımsız hâkim ve savcılardan oluşan bölge adliye mahkemeleri bilirkişiliğin idari bürokrasisi açısından neyi eksik yahut yanlış yapmıştı ki, yeni yapı bunlara çözüm getirecektir. Bunun yerine, ayrı ve merkeziyetçi bir idari yapılanma öngörülmüş bulunması, bilirkişilik müessesesi açısından uygulamada yaşanan hiçbir soruna çare olmayacaktır." görüşündedir.
}

15 Rehber için bkz. https://bilirkisilik.adalet.gov.tr/Home/SayfaDetay/bilirkisilerin-uyacagi-rehber-ilkeler-vebilirkisi-raporlarinda-bulunmasi-gereken-standartlar26032021121159, E.T:7.05.2021. 
4-Bilirkişi, iddia ve savunmalarla ilgili yorumda bulunamayacak.

5-Bilirkişi, raporunu hazırlarken raporun dayanağı olan somut ve özel nedenleri bilimsel verilere uygun göstermek zorunda olacak.

6-Değerlendirmede kullanılmak üzere ölçüm yapılması gerektiğinde de bilirkişi, bu ölçümleri bizzat yapacak, tarafların verdikleri ölçümleri esas alarak değerlendirme yapamayacak, hesaplamada esas alınan birim fiyatlar ve dayanılan kriterlere raporda açıklamalı yer verilecek.

7-Bilirkişi, raporunda kesinlikle takdiri değerlendirmelerde bulunmayacak, somut olayı tüm açıklığıyla raporunda anlattıktan sonra olayın yorumunu ve takdirini hakime bırakacak.

8-Bilirkişi, raporunu hazırlarken hukuki nitelendirme ve değerlendirmelerde bulunamayacak, tereddüt ettiği hallerde görevlendirmeyi yapan merciden hukuk sorunu ve inceleme alanının kapsam ve sınırları hakkında bilgi isteyebilecek.

9-Bilirkişinin, özel veya teknik bilgiye dayanmadan yalnız yargılama sırasında elde edilen delilleri değerlendirerek uyuşmazlık konusu hakkında saptamalar ve yorum yapmasının bilirkişilik temel ilkelerine aykırı olduğu göz önünde bulundurulacak.

10-Bilirkişi, sorunu çözerken kullanacağı özel veya teknik bilgisinin değerlendirilmesinde delillerden yardımcı ya da denetleyici olarak yararlanabilecek.

11-Bilirkişi, raporunu hazırlarken teknik terim ve kavramlarla ilgili sözcüklerin Türkçe karşılıklarını tercih edecek ya da parantez içinde Türkçe karşılıklarını mutlaka yazacak, teknik bir kavram söz konusu ise ayrıntıya kaçmadan bu kavramla ilgili açıklamada bulunacak. Ayrıca, bilirkişi raporunu hazırlarken görevlendiren merci tarafından istenmesi halinde yargılama sırasında dosyaya sunulan uzman görüşlerini de özel ve teknik bilgi yönünden değerlendirebilecek.

12-Bilirkişi, raporunda tümüyle maddi olgulara yer verecek, cevaplaması istenen somut soruları tek tek sorulma sırasına göre, bilimsel dayanaklarını da açık ve anlaşılır biçimde gösterecek, eksiksiz cevaplayacak.

13-Bilirkişi, hakimin yetkisinde olan kusurluluk konusunda (asli/tali kusurlu, kusursuz, yüzdelik kusur oranı) herhangi bir değerlendirme yapamayacak.

14-Dosyada daha önce alınan bilirkişi raporları arasındaki çelişkinin giderilmesi için yeniden rapor düzenlemek üzere görevlendirilme halinde bilirkişi, birbiriyle çelişen raporlardaki tespit ve değerlendirmelerden hangilerine katıldığını veya farklı bir görüş ve değerlendirme sunacak ise bunun nedenlerini tartışıp gerekçelendirerek raporunu düzenleyecek.

15-Bilirkişi, dosyada ek rapor alınmak üzere görevlendirildiğinde, ek raporun alınma gerekçesi çerçevesinde soruna çözüm üretecek mahiyette ve tekrar ek rapor alınmasına gerek duyulmayacak nitelikte rapor düzenleyecek.

16-Öte yandan, bilirkişi, hazırlayacağı raporda özel ve teknik bilgisini kullanarak ulaştığı sonuçların gerekçesini de açıklamakla yükümlü olacak.

Rehber ilkelerde ifade edilen bu hususlara tamamen riayet edilerek ve süresinde hazırlanmış bir raporun varlığı halinde maddi gerçeğin bulunabilmesine yardımcı olacak, hâkimin konuyla ilgili soru işaretlerini ortadan kaldıracak, tam anlamıyla hukuka ve işleve uygun bir 
bilirkişilik gerçekleştirilmiş olacaktır. Bununla beraber bilirkişi raporlarının içeriğinde bulunması gereken hususlar sadece Daire Başkanlığının belirlediği ilkeler ile sınırlı değildir. Uygulamaya yön veren Yüksek Mahkeme Yargıtay'ın da bilirkişi raporlarının nasıl olması gerektiği ve içeriğinde bulunması gereken hususlara yönelik yaklaşımları mevcuttur. Yargıtay tarafından yerel mahkeme kararları üzerinde en sık denetimi yapılan ve bozma kararlarına esas teşkil eden iki ilke 'yetkinlik' ve 'tarafsızlık'tır. Bilirkişinin en önemli özelliklerinin başında alanında uzman ve tarafsız olması gelmektedir. Nitekim Yargıtay’ın çeşitli dairelerince verilmiş kararların analizinde; • "Konunun ne şekilde uzmanı olduğu anlaşılamayan bilirkişi görüşüne itibarla hüküm tesisi." • "İhtisas derecesi anlaşılamayan kişinin dayanaksız mütalaasına dayanılarak beraat kararı verilmiş olması." • "Bitkinin hint keneviri olduğunun uzman bilirkişi raporu ile saptanmaması." • "Dava konusu emvalin fatura ve nakliye tezkeresine uygunluğu hususunda uzman bilirkişi incelemesi yaptırılmadan beraate karar verilmesi." - "Dava konusu içki, çay ve Çin malı tabakların CIF değerlerinin bu konuda uzman bilirkişi yerine gümrük komisyoncusu olan bilirkişiye tespit ettirilmesi." • "Kaçak malın değerinin tarafsız bir bilirkişi yerine Gümrük ve Tekel İdaresinde memur olan bir bilirkişiye tespit ettirilmesi." -Grafoloji dalında özel uzmanlığı bulanan bir bilirkişiden rapor aldırılması gerekirken adli tıp doktorundan alınan rapora dayanılması." Gibi sebeplerle birçok kararın bozulmasına karar verildiği görülmekte; bilirkişinin mutlak surette tarafsız, özel bilgi ve uzmanlık sahibi kişi olmasının istendiği anlaşılmaktadır. ${ }^{16}$

Yine bu kapsamda uygulama da en çok hata yapılan belgede sahtecilik suçlarındaki bazı özelliklere değinmek gerekirse; bu suçlarda belgenin "iğfal kabiliyeti” yani "aldatıcılık özelliği”" bu suçun temel unsuru olup, özel bir incelemeye tabi tutulmadıkça gerçek olmadığı anlaşılamayan belge, sahte belge olarak kabul edilmektedir. Sahteciliğin kişileri aldatacak nitelikte olup olmadığı, aldatma unsurunun belgeden objektif olarak anlaşılması gerektiği, muhatabın hatasından, dikkatsizlik ve özensizliğinden kaynaklanan fiili iğfalin, aldatma yeteneğinin varlığını göstermeyeceğini Yargıtay birçok kararında kabul etmiştir. Yargıtay ayrıca belge incelemesine esas imza karşılaştırmasının, belgenin hazırlanışından sonraki tarihte atılmış imza örnekleriyle yapılmış olmasını bozma sebebi kabul ederek, incelemenin şüphelinin belgeden hem önceki hem de sonraki tarihe ait örneklerle yeniden yapılmasını gerekli görmüştür. Bilimsel olarak bilirkişiye gönderilen mukayese edilecek imza örnekleri ile şüpheli imzanın atılış tarihi arasında beş yıldan fazla süre olmaması gerektiği de kabul edilmiştir ${ }^{17}$

Çelişkili bilirkişi raporlarının dosyadaki varlığı da bir başka sorun olarak göze çarpmaktadır. Yargıtay'ın vermiş olduğu bazı kararlarda yapılacak incelemenin metodunu, hâkimin birinci veya ikinci raporlara göre karar veremeyeceği bu durumda üçüncü kez bilirkişi incelemesi yaptırılması gerektiği bunun yanı sıra birden fazla bilirkişinin görevlendirildiği işlerde azınlıkta kalan bilirkişi raporunu esas alarak hüküm verilemeyeceğini ve çelişkili bilirkişi raporları varsa hangi yöntemle hareket edilmesi gerektiğini uygulamaya yön verecek şekilde açıklamıştır. ${ }^{18}$

${ }^{16}$ Karaburun, Gökhan. “Karar Örnekleriyle Yargıtay'ın Bilirkişiliğe Bakışı ve Bilirkişiliğin Sorunları”Adli Tıp Bülteni, C.22, S.3, İstanbul 2017, s.200.

${ }^{17}$ Karaburun, s.201-202.

${ }^{18}$ Yargitay 12. Hukuk Dairesi ise 22.02.2004 tarihli (E.2004/5818, K.2004/10153) kararında "bilirkişi raporunda hangi ortamda ne tür teknik cihazlar kullanılarak inceleme yapılıp sonuca varıldığının açıklanmadığını, sadece grafolojik ve grafometrik metotların uygulandığının belirtildiği, ulaşılan sonucun maddi dayanaklarının denetime elverişli şekilde ortaya konmadığını, bu itibarla bilirkişi raporuna dayanılarak hüküm kurulamayacağını," belirterek kararı bozmuştur. 
Birçok Yargıtay kararında bilirkişi raporları arasında- ki çelişkinin giderilmesi için Adli Tıp Kurumuna başvurulması gerektiği işaret edilmekteyse de bu husus sadece yerel mahkemeye yön göstermek amaçlı olup, 2659 sayll Adli Tıp Kurumu Kanununun 23/C-3 maddesi de dikkate alındı ̆̆ında Adli Tıp Kurumunun resmi bilirkişi sıfatı bulunmasının onu son merci yapmayacă̆ ve kurum tarafindan verilen raporlara sırf bu nedenle üstünlük tanınmayacă̆ açıktır. Yargıtay 12. Hukuk Dairesi 20.03.2007 tarihli (2007/2366-5280 esas ve karar sayıl1) kararında "Adli T1p Kurumu grafoloji (bugün adli belge inceleme şubesi olarak ismi değiştirilen bölüm kastedilmektedir) bölümünün imza incelemesinde son merci olarak kabulünün mümkün bulunmadığını" belirtmiş, yine aynı daire 26.11.2012 tarihli (2012/17547E, 34790K) kararında “Adli Tıp Kurumu Fizik İhtisas Dairesinin imza incelemesinde son merci olarak kabulü mümkün bulunmayıp, raporun anılan kurumdan alınmış ve heyetçe düzenlenmiş olması da yerleşik Yargıtay içtihatlarına göre ona üstünlük tanımayacağından anılan rapora itibar edilerek sonuca gidilemez." demek suretiyle bu hususu vurgulamıştır. ${ }^{19}$ Doktrinde de aynı kurumlara bağlı makamların delilleri değerlendirmesi kuvvetler ayrılığı ilkesini zedeler nitelikte olduğunu, Adalet Bakanlığına bağlı Adli Tıp Kurumu gibi resmi bilirkişilik kurumlarının varlığının bilirkişi yönünden eşitlik ilkesine aykırılık oluşturduğunu iddia eden görüş sahipleri vardır. ${ }^{20}$

\section{V- Bilirkişinin Görevlerini Yapmamasının Yaptırımları}

CMUK döneminde bilirkişi adliyeye gitmez ya da kabul etmesine rağmen süresi içinde raporunu sunmazsa, 765 sayılı TCK m. 282'ye atıf yapılmaktayd1. Bu madde, kanunen yerine getirilmesi gereken bir görevin yerine getirilmemesini düzenlemektedir. Bu bir kabahat idi ve bilirkişiye disiplin hapsi uygulanabileceği hükmü düzenlenmekteydi. Yeni ceza sistemimizde 765 s. TCK m. 282'ye karşı1ık gelen bir hüküm yoktur. CMK m. 60'a atıf yapılmaktadır. Bu madde, tanığa uygulanan bir hükümdür atıf gereği bilirkişi hakkında da uygulanabilir. CMK m 71 e göre usulüne uygun olarak çağırıldığı halde gelmeyen veya gelip de yemin etmekten, oy ve görüş bildirmekten çekinen bilirkişiler hakkında CMK md 60/1 de tanıklar bakımından düzenlenen maddeye atıf yapılarak yaptırım uygulanması öngörülmüştür. Bir görüşe göre yapılan yollamanın sınırlı olması özellikle disiplin hapsi kararına itiraz edilebilmesini düzenleyen CMK md 60/son un uygulanmasını olanak dışı bırakması nedeniyle doğru bulunmamaktadır. $\mathrm{Bu}$ durumun adil yargılamayı zedelediği söylenmektedir. ${ }^{21}$ Oysa ki hükümde kanun yoluna başvurmayı etkileyen veya engelleyen bir durum olmadığı kanaatindeyiz. Ama başta yakalamaya ve gözaltına alınmaya itiraz olmak üzere uygulama sürelerinin zaten çok kısıtlı olduğu bazı müesseseler çerçevesinde haklı bir eleştiridir. Öte yandan Muhakeme kanunumuza kaynak teşkil eden Alman Ceza Muhakemesi Kanunu (StPO) nun konuyu düzenleyen 77.maddesi CMK 60 tan müeyyide yönüyle farklı olmakla beraber(disiplin hapsi yerine disiplin para cezası) gerek müeyyidenin takdiri olmayaşı, gerek uygulanan disiplin para cezasına yönelik herhangi bir kanun yoluna başvuru hakkı tanımaması çerçevesinde çok daha katıdır.

\footnotetext{
${ }^{19}$ Karaburun, s.202-203.

${ }^{20}$ Batum, Süheyl/Yenisey Feridun/Erkut Celal/ İnceoğlu Sibel, AİHS ve Adil Yargllanma İlkesi Işı̆̆ında Hukuk Devleti ve Yargı Reformu, Tüsiad Yayınları, İstanbul 2003, s.102; Yenerer Çakmut, s.157.

${ }^{21}$ Özbek, Veli Özer. "Tıbbi Deliller ve Yeni Ceza Muhakemesi Kanunu”, Yeditepe Üniversitesi Hukuk Fakültesi Dergisi, C.3 S.2, 2006, s.399.
} 
CMK m. 60, üç aylık disiplin hapsi ve zararların giderilmesini hükme bağlamaktadır. Fakat önceden de söylediğimiz gibi bu yol çok nadiren işletilmektedir. Bununla beraber Bilirkişilik Kanununun "Bilirkişilik listesinden ve sicilinden çıkarılma" başlıklı 13.maddesi bu yaptırımın hangi hallerde uygulanacağını tahdidi olarak saymaktadır. Fakat uygulamada bu maddenin gereklerinin de titizlikle yerine getirildiğini söylemek mümkün değildir.

TCK'da gerçeğe aykırı bilirkişilik yapmak cezalandırılan bir eylemdir. Kanunun 276. maddesinde düzenlenen, gerçeğe aykırı bilirkişilik veya tercümanlık suçunun lafzı bazı sorunlar yaratacak nitelikte olsa da böyle bir suç tipinin mevcudiyeti son derece önemlidir. Yargıtay 4. Ceza Dairesi 19.07.2007 tarihli kararında "bilirkişilerin icra müdürlüğünce kıymet takdiri yapılmak üzere görevlendirdikleri konutu görmeden değer tespiti yaparak rapor düzenlemelerini TCK 276. maddesine uyan "gerçeğe aykırı bilirkişilik" suçunu oluşturacağını" belirtmiştir. ${ }^{22}$

\section{VI-Bilirkişilik Müessesesi Çerçevesinde Eleştirilerimiz}

Gerek CMUK gerek CMK ve hatta HMK bilirkişilik konusunun yargılama için öneminin altını çizer şekilde çok fazla madde adedi ile geniş ve ayrıntılı düzenlemeler yapmıştır. Buna rağmen sorunlar giderilememiş, kanunkoyucu 2016 y1lında müstakil bir Bilirkişilik Kanunu ihdas etmiştir. Kanunun Adalet Bakanlığı tarafından hazırlanan genel gerekçesinde, yeni bir "bilirkişilik kanunu" hazırlamayı zorunlu kılan hususların üç noktada toplandığı görülmektedir. Bunlardan birincisi, kurumsal yapı eksikliği; ikincisi bilirkişiliğin bir meslek olarak kabul edilmemiş olması ve nihayet üçüncüsü ise hukuki konularda bilirkişiye müracaatın adeta yargı yetkisinin devri sonucu doğurmasıdır. Bununla birlikte, mevcut liste uygulamasının bilirkişilik kurumundan beklentileri tam olarak karşılayamadığı da ayrıca vurgulanmış, bu durumun yargılama faaliyetlerinin uzamasına neden olacak şekilde mağduriyetlere ve şikayetlere sebebiyet verdiği belirtilmiştir. Gerekçede vurgulanan hususlara genel olarak katılmakla birlikte yapılan iyiniyetli düzenlemenin, yaranın kanamasını dindirmediğini de söylemek zorundayız. Kanaatimizce sorun bilirkişilik teşkilatlanmasında olmayıp çözümü de kontrol ve uygulamayı İl Adli Yargı komisyonlarından alıp merkezi otoriteye bağlamak değildir. Bir görüşe göre yargısal alana özgü bir işlev üstlenen bilirkişilik bu açıdan daha az yürütme ile daha çok yargı ile ilişsilendirilerek tesis edilmelidir. ${ }^{23}$

Şüphesiz ki bakanlık bünyesinde kurulan Daire Başkanlığı bilirkişilik uygulamalarına yönelik bir takım eğitim programları da yürütmektedir. Hatta kanundan önce herkesin ağız birliği yapmışçasına vurguladığı bilirkişi sicili oluşturulması ve dosya dağıtımının sicildeki başarı durumuna göre yapılması hususları da mevcut kanun çerçevesinde çözüme kavuşturulmuştur. Fakat kabul edemediğimiz ve düzeltemediğimiz gerçek, yasalarımız yeterince kapsayıcı olsa da mer'iyette olan normları uygulama konusundaki keyfiliğimizdir. Bilirkişilik konusundaki sorunların temel sebebi ne kurumsal yapı eksikliği ne de düzenleme ve yaptırım konusundaki mevzuattır. Kanaatimizce sorun kalite sorunudur. Bir kamu görevinin ifası anlamında yargısal faaliyetlere gerçekten uzmanlığı ile yardımcı olmak isteyen çok az sayıda bilirkişiyi tenzih ederek söylemeliyiz ki ülkemizde bilirkişilik yapan gerçek kişilerin çok büyük bölümü, asgari ücret tarifesinden belirlenen cüzi bilirkişilik ücretlerine talip olarak ek gelir elde etme amacındadır.

\footnotetext{
22 Karaburun, s.203.

${ }^{23}$ Karaburun, s.207.
} 
Mesleğini kamuda veya özel sektörde başarı ile ifa edip, uzmanlık dereceleri çerçevesinde tercih gören ve bunu da gelire tahvil edebilen kişiler arasında bilirkişilik yapmak tabir caiz ise angarya ve vakit kaybı olarak kabul edilmektedir. Hal böyle iken herhangi bir uzmanlık alanından, zanaat kabul edilen işlere kadar her alanda durum bundan ibarettir. Bilirkişi derneklerinin web sayfalarında yapılan açıklamaların hemen hepsinde adaletsiz dosya dağıtımı en büyük sorun olarak gösterilmektedir. Dosya başına verilen cüzi ücret, ayda yazılan rapor sayısı arttıkça özellikle emekli olmuş uzmanlık sahipleri için bir geçim kaynağı olarak kabul edilmektedir. Bilirkişilik açısından zikrettiğimiz bu nitelik sorunu aslında Türkiye'deki yüksek öğrenimin ve uzmanlık eğitiminin de kalitesiyle yakından alakalıdır. Üzülerek ifade etmeliyiz ki diplomalı uzman sayımız ciddi boyutta olsa da nitelikli uzman sayımız son derece azdır. Hal böyleyken kanunkoyucu hukukçulara yönelik yapmış olduğu düzenlemede kendi kuralının arkasından dolanırcasına başka uzmanlık alanları olması halinde hukukçuların da bilirkişilik yapabilmesine cevaz vermiştir. Türkiye Barolar Birliğinden kısa sürelerde alınan sertifikalarla yeni uzmanlık alanları doğmuş, aynı yargı çevresinde faaliyet gösteren avukatların aktüerya uzmanı, iflas uzmanı gibi sıfatlarla bilirkişi listelerine girebilmelerine olanak sağlanmıştır. İş Mahkemelerinde kıdem ve ihbar tazminatları yıllarca avukat bilirkişiler tarafından hesaplanmıştır. Bunun için hesap uzmanı olmaya gerek yoktur ve ayrıca avukat hesap uzmanı değildir. Son derece basit yazılımların UYAP sistemine dahil edilmesiyle hakimler tazminat hesaplama imkanına sahiptir. Zorunlu müdafilik, Uzlaştırıcılık gibi uygulamalara öncelikle talip olan meslektaşlar genellikle bunu belirli sebeplerden yapmaktadır. Söylemek istediğimiz şudur ki bilirkişiliğe talip olanların büyük kısmı aynı sebeplerle bu iş için kolları sıvamakta ve yazdıkları raporlar ceza yargılamasının temel amacı olan maddi gerçeğe ulaşma konusunda büyük problemler yaratmaktadır.

Raporların süresi içinde gelmemesi de çokça zikredilen bir başka problemdir. Eğer listeden çıkarılma konusunda tavizsiz davranılırsa ve Hakimler CMK nun 60.maddesinde belirtilen yaptırımı kararlı şekilde uygularlarsa bu sorunun kolaylıkla çözüleceğinden kimse kuşku duymamalıdir.

Kanaatimizce çeşitli sebepler ve mazeretler öne sürülerek uygulanmayan bir başka yasal düzenleme, bilirkişinin duruşmaya davet edilerek raporu hakkında açıklamalarda bulunmasının istenmesidir. Kanunun cevaz verdiği bu uygulama, maddi gerçeğin çok daha hızlı ve isabetli olarak tespit edilmesine büyük fayda sağlayacaktır. Ayrıca Ceza Muhakemesi Kanununun 201.maaddesinde yer alan "doğrudan soru yöneltme" imkânı sayesinde bilirkişi raporunun eksik ve hatalı yanları çok hızlı şekilde ortaya çıkarılabilecek, yazılı rapora itiraz ederek evrak üzerinde yeni tartışmalarla vakit kaybedilmeyecektir. Öngörülebileceği üzere bilirkişinin niteliği, konuşma hakimiyeti ve alanındaki başarıları raporun kuvvetini arttıran etkilerdir. Özellikle aynı konuya ilişkin farklı bilirkişilerden rapor veya görüş alındığı durumlarda görüşler arasında farklılıkların bulunması halinde niteliğin önemi daha da ön plana çıkmaktadır. Bu kapsamda duruşma sırasında dinleme ve doğrudan soru yöneltme araçları ile; bilirkişinin vasıfları, dereceleri, eğitimi, konumu, profesyonel meslek gruplarına üyelikleri, bilirkişilik yaptığı alandaki uzmanlığı ve bunları nasıl elde ettiği gibi hususlar bilirkişiye bizzat onaylattırılarak ortaya konacak, kesin ve doğrudan sorular ile varsa rapordaki teknik husus veya kullanılan dilin açıklattırılması sağlanmış olacaktır. ${ }^{24}$ Daha da önemlisi delillerin doğrudan doğruyalığı prensibi çerçevesinde hakim, değerlendirme

${ }^{24}$ Karaburun, s.207. 
yaparken mümkün mertebe delillerle beş duyusu aracılığı ile temasa geçmelidir. Kanun buna imkân tanıyorken bunu kullanmamanın yargılamaya maliyeti çok daha fazladır. Zira Bilirkişi raporlarının huzurda tartışılması hakimin bir kanaate ulaşması bakımından son derece faydalıdır. ${ }^{25}$

Konuya ilişkin Avrupa İnsan Hakları Mahkemesi de maalesef bilirkişilik uygulamalarımız hakkında olumsuz değerlendirmeler yapmakta ve kararlar vermektedir. AİHM, Türkiye ile ilgili olarak önüne gelen pek çok dosyada özellikle adli raporların yüzeysel ve amaca uygun olmadığını, genel ifadelerle yetinildiğini belirtmekte, özellikle savcllıklardan adli tabipliklere gönderilen müzekkerelerde neden muayene istendiğinin yazılmamasının, otopsiyi gerçekleştiren hekimlerin yeterli deneyim ve bilgiden yoksun bulunmalarının, otopsi ve ölü muayene tutanaklarında incelemenin başlama saati, cesetteki yaraların uzak, yakın veya bitişik atış sonucunda mı olduğuna değinilmemesinin, ölü morluğu ve katılığının oluşup oluşmadığının açıklanmamasının, cesedin bulunduğu yer ve konumuna ilişkin bilgilerin verilmemesinin önemli eksikler olduğunu ifade etmektedir. ${ }^{26}$ Daha da çarpıcı bir örnek bilirkişinin süreye riayet etmemesi noktasında kendini göstermiştir. Avrupa İnsan Hakları Mahkemesinin 21.12.2006 tarihli Oruç /Türkiye (33620/02) kararında; "Dava konusu olayda mahkemenin sahte olduğu iddia edilen evrakın yorumlanması için dava dosyasını bilirkişiye göndermiş olması ve takip eden yedi (7) duruşma boyunca bilirkişiden cevap alınamaması ve duruşmanın yeniden ertelenmesi nedeniyle başvurucunun yargılama süresinin AİHS m. 6/1 de düzenlenen makul sürede yargılanma hakkının ihlal edildiğine dair" karar vererek başvurucunun talebini yerinde görmüş ve Türkiye'yi AİHS'in 6/1 maddesini ihlal etmekten sorumlu bulmuştur. ${ }^{27}$

\section{SONUÇ}

Bilirkişiler, amacı maddi gerçeğe ulaşmak olan ceza yargılamasına uzman olduğu teknik ya da özel bilgisiyle yardımcı olan önemli bir unsurlardır. Ceza muhakemesinde çözümü uzmanlık, özel ve teknik bilgi gerektiren bir konuda kural olarak hâkim veya mahkeme kararı ile görüşüne başvurulan bilirkişi yargılama süreci içerisinde, hâkim yerine geçmemekle birlikte verilecek hükümde büyük ölçüde belirleyici ve etken bir rol oynamakta, böylelikle adalet hizmetinin işleyişine katkıda bulunmaktadır. Fakat çalışmamız boyunca belirttiğimiz bazı sorunlar yıllardır çözülememiş, yargıdaki iş yükü arttıkça çoğu zaman göz ardı edilmiştir. Gerek her uzmanlık alanında yeterince yetkin uzman bulunamaması, gerek bilirkişilerin uygulamacı ve bakanlıkça gösterilen onca hoşgörüye rağmen hala usulüne aykırı raporlar düzenlemeleri problemlerin devam etmesindeki en temel etkenlerdir. Resmi Bilirkişi olarak görev yapan Adli Tıp kurumunun yeniden yapılandırılması, Bilirkişilik kanununda yetkilendirilen özel hukuk tüzel kişilerinin temel bir akreditasyon sürecinden geçirilme zorunluluğunun bulunmaması, bilirkişilik ücretinin sembolik

\footnotetext{
${ }^{25}$ Şahin Cumhur/Göktürk Neslihan, Ceza Muhakemesi Hukuku II, Seçkin Yayıncılık, 7.Baskı, Ankara 2018, s.142. ${ }^{26}$ Centel, Nur, “Adli Tıp Bilimleri ve Insan Hakları” AÜEHFD, C.4, S.1-2, 2000, s.16-17, Yenerer Çakmut, s. 152. ${ }^{27}$ AİHM ulusal mahkemenin bir yılı aşkın bir süre sahte olduğu iddia edilen evrakla ilgili bilirkişi raporunu beklemiş olduğunu gözlemler. Benzer şekilde Adli Tıp Kurumu'ndaki grafoloji uzmanının belgelerde bulunan el yazısı ve imzaların başvurana ait olup olmadığını belirlemesi dokuz ay almıştır. Her iki dönemde de mahkeme esas veya usule ilişkin bir karar almadan duruşmaları ileriki bir tarihe ertelemiştir. Mahkeme ayrıca Adli Tıp Kurumu uzmanlarının dava dosyası hakkındaki görüşlerini sunmalarının yaklaşık on altı ay sürmüş olduğunu gözlemler. Buna ek olarak sözkonusu uzmanların dava dosyasını mahkemeye geri göndermemiş olması takibatın beş ay daha uzamasına neden olmuştur. Karar için bkz https://www.kararara.com/aihm/turkce3/aihm11476.htm E.T, 06.05.2021.
} 
oluşu, süre şartına riayet etmeyen bilirkişilerin istisnasız bir şekilde kanundaki yaptırımla karşılaşmamaları müessese çerçevesindeki sorunları büyütmektedir. Elbette ki en önemli husus yüksek öğrenim kurumlarındaki lisans ve özellikle lisansüstü eğitimin gün geçtikçe nitelik olarak kan kaybetmesi sonucu bu programları bitiren pek çok kişinin uzmanlık vasfinı gerçek anlamda hak etmemesidir. Yargılama hukukumuzda bilirkişilik müessesesinin önemini azaltılamayacağına göre müessesenin güvenilirliğini arttırmak için gerekli tedbirler bir an önce alınmalıdır. Aksi takdirde tıpkı elli yıldır tartışıldığı gibi bir o kadar daha tartışılmaya, eleştirilmeye, "kanayan yara" olarak nitelendirilmeye devam edecektir.

\section{KAYNAKÇA}

Atal1, Murat. "6754 sayılı Bilirkişilik Kanunu ve Hukuki konularda Bilirkişilik” Ankara Üniversitesi Hukuk Fakültesi Dergisi Cilt 65, S4, s. 3271-3282.

Batum, Süheyl/Yenisey Feridun/Erkut Celal/ İnceoğlu Sibel. AIHSS ve Adil Yargllanma Illkesi Işı̆̆ında Hukuk Devleti ve Yargı Reformu, TÜSİAD Yayınları İstanbul 2003.

Centel, Nur. “Adli Tıp Bilimleri ve İnsan Haklart” AÜEHFD C.4, S.1-2 2000, s.3-19.

Çakmut Yenerer, Özlem. "Cinsel Taciz Suçu ve Ceza Muhakemesi Kanununa Göre Bilirkişilik Кигитu” Ceza Hukuku Dergisi S.11, 2009, s.129-160.

Deryal, Yahya. Türk Hukukunda Bilirkişilik, Seçkin Yayıncılık, Ankara 2015.

Dönmez Burcu. "Yeni CMK'da Bilirkişi Kavramı" Dokuz Eylül Üniversitesi Hukuk Fakültesi Dergisi C.9, 2007, s.1145-1177.

Dülger, İbrahim. “Ceza Muhakemesi Kanunundaki Bilirkişi İncelemesine İlişkin Düzenlemelerin Değerlendirilmesi”, GÜHFD, C. 11, S. 2007/1-2 (Yrd. Doç. Dr. İbrahim Ongün’e Armağan) s.657-678.

Karaburun, Gökhan. “Karar Örnekleriyle Yargıtay’ın Bilirkişiliğe Bakışı ve Bilirkişiliğin Sorunları” Adli Tip Bülteni, C.22, S.3, 2017, s.200-207.

Özbek, Veli Özer. “Tibbi Deliller ve Yeni Ceza Muhakemesi Kanunu” Yeditepe Üniversitesi Hukuk Fakültesi Dergisi C.3, S.2, 2006, s.357-406. 2018.

Şahin Cumhur/Göktürk Neslihan. Ceza Muhakemesi Hukuku II, Seçkin Yayıncılık 7.Bask1 Ankara

Ünver Yener. “Ceza Muhakemesinde İspat, CMK ve Uygulamamız” Ceza Hukuku Dergisi, C.1, S.2, 2006, s.103-205. s.49-107.

Yokuş Sevük, Handan. "Ceza Muhakemesi Hukukunda Bilirkişilik” İHFM, C.LXIV, S.1, 2006,

Yurtcan, Erdener. Ceza Yargllaması Hukuku, İstanbul 2005.

\section{WEB KAYNAKLARI}

https://bilirkisilik.adalet.gov.tr/Home/SayfaDetay/bilirkisilerin-uyacagi-rehber-ilkeler-ve-bilirkisiraporlarinda-bulunmasi-gereken-standartlar26032021121159 E.T 7.05.2021.

https://www.kararara.com/aihm/turkce3/aihm11476.htm E.T 06.05.2021. 